\title{
Gender Differences in Social Relationships and Social Support of School Children
}

\author{
Om Parkash $^{1 *}$
}

\section{ABSTRACT}

The objective of the current study was to investigate the gender differences in social relationships and social support of school children. Total 165 (65 Males and 100 Females) school children participated in the study from different four senior secondary schools of Punjab. The age of the subjects ranged between 15 to 18 years with a mean age of 16.96 years. Social Relationships Scale and The Interpersonal Support Evaluation List have been used to collect data for social relationships and social support respectively. The results indicated no significant gender difference on overall social relationship and six dimensions of social relationship including parents, peers, siblings, teachers, relatives and strangers. However, a significant difference has been observed on the friend dimension $(\mathrm{P}<.01)$, being males on the higher side. Similarly, males also scored significantly higher on perceived social support $(\mathrm{P}<.05)$ than females. The results confirm the notion that females perceive low social support not only at higher stage of life, but this difference is rooted in their childhood and adolescent period also.

Keywords: Social Relationships, Social Support, School Children

Social relationship is considered the relationship between two or more people. Social relationships have many facets including family, friends and relatives. Social relationships and social support are strongly related and it has been found out in many studies that people having high social support are better on physical and mental health parameters. Schwarzer and Leppin (1991) also demonstrated that there is a strong positive relationship between social support and physical and mental well-being. According to Albrecht and Adelman (1987) social support is the "verbal and nonverbal communication between recipients and providers that reduces uncertainty about the situation, the self, the other, or the relationship, and functions to enhance a perception of personal control in one's life experience” (p. 19).

One research by International Centre for Life course Studies in Society and Health suggested that social networks have significant positive effects on a person's psychological health. Attachment

\footnotetext{
${ }^{1}$ Research Scholar, School of Education, Lovely Professional University, Punjab, India

*Responding Author

(C) 2016 Parkash O; licensee IJIP. This is an Open Access Research distributed under the terms of the Creative Commons Attribution License (http://creativecommons.org/licenses/by/2.0), which permits unrestricted use, distribution, and reproduction in any Medium, provided the original work is properly cited.
} 


\section{Gender Differences in Social Relationships and Social Support of School Children}

theory introduced by Bowlby (1969) have proposed the notion that children who received safety and security in childhood are better in maintaining their relationships if different areas such as school, work or friendship. The attachment theory also suggests that childhood relationship experiences are crucial and affect the maintenance of relationships in later life.

In the last three decades, numerous researches have suggested that social relationships and social support are vital for a person's physical and mental health. However, the researches to identify the key determinants of social support and social relationships, especially in school children, are yet less studied. In this light, the current research targets to study the gender differences in social relationships and social support of school children.

Belle (1987) has argued that gender differences in interpersonal behavior and relationships are clearly visible throughout the life cycle and this ensures that women and men differ on social relationships. Walen and Lachman (2000) investigated the gender differences of social support and strain from partner, family, and friends among different age groups as young 25-39 years, middle 40-59 years, and older 60-75 years. The results suggested that social networks consistently differ by sex and age and there exists significant sex differences on social support and networks.

Matud et al. (2003) also examined gender differences in social support. The sample included 3210 participants with age ranging from 18 to 65 years with a mean age of 34.1 year. The researchers concluded that there is clear evidence of gender differences in perceived social support and this difference can be due to the different socialization and social roles performed by men and women.

Kumar et al. (2016) conducted a study to investigate the association and gender differences of social relationships among University students. Total 279 students participated in the study with an age range of 17 to 25 years. To collect data for social relationship, the Social Relationships Scale had been used. The results of the study suggested no significant gender differences on different dimensions of social relationships.

On the basis of above studies, we can say that there is no consensus over the association of gender differences in relation to social relationships and social support. The literature review also suggests that different age groups show variation in gender differences in context to social relationships and social support. The current study has also been done to get more clarity on gender differences for social relationships and social support. For fulfilling this objective, the below mentioned methodology has been used. 


\section{Gender Differences in Social Relationships and Social Support of School Children}

\section{METHODOLOGY}

\section{Sample}

The current study involved 165 (65 Males and 100 Females) school children from different four senior secondary schools of Punjab. The age of the subjects ranged between 15 to 18 years with a mean age of 16.96 years. All the students were selected on the random basis and the sample involved students from different streams including arts, commerce and science.

\section{Research Tools}

1. Social Relationships Scale (SRS): This scale has been developed by Pardeep Kumar, Faheem Nabi and Neha Thakur in 2016. The scale has total 35 items divided into seven different dimensions of social relationships. The seven dimensions of the scale include friends, siblings, parents, relatives, classmates, teachers and strangers. The scale has been standardized on the population of adolescents and young adults age ranging from 15 to 30 years. The test - retest reliability of the scale is .93.

2. Interpersonal Support Evaluation List: The Interpersonal Support Evaluation List (ISEL) has been developed by Cohen et al. in 1985 to measure the functional components of social support. The scale has total 40 items which further divided into four sub types. The four sub types of the scale include tangible support, appraisal support, self-esteem support, belonging support. 20 items of the scale in positive direction and the other 20 in negative direction to counter balance the social desirable behaviour of the participant. The internal reliability for the ISEL is between 0.88 and 0.90 and the test-retest correlation is .87. The ISEL was also strongly (.74) correlated to the Rosenberg Self-Esteem scale.

\section{Procedure}

First of all, four schools have been selected from Jalandhar and Kapurthala District of Punjab on convenience basis. Total 165 students randomly selected from the four schools to participate in the study. The participants were given Social Relationships Scale and The Interpersonal Support Evaluation List to measure the level of social relationships and social support of the participants. The instructions were given to the participants and it is ensured that they understood everything about the scale. It took about 40 minutes to complete both the scale by the participants. The collected data have been analysed for any missing value or outliers and then independent samples $\mathrm{t}$ test has been computed through SPSS for data interpretation.

\section{RESULTS AND DISCUSSION}

The results of the study have been presented in table 1. The table presents Means, SDs, t scores and $\mathrm{p}$ values for overall social relationship, social support and seven dimensions of social relationships. 
Gender Differences in Social Relationships and Social Support of School Children

Table 1: Means, SDs, $t$ scores and $p$ values for overall social relationship, social support and seven dimensions of social relationships

\begin{tabular}{|c|c|c|c|c|c|}
\hline$N=165$ & Gender & Mean & Std. Deviation & t ratio & p value \\
\hline \multirow[t]{2}{*}{ Overall SRS } & Male & 127.45 & 17.16 & \multirow[t]{2}{*}{1.73} & \multirow[t]{2}{*}{0.09} \\
\hline & Female & 123.22 & 14.06 & & \\
\hline \multirow[t]{2}{*}{ Social Support } & Male & 36.03 & 6.85 & \multirow[t]{2}{*}{2.34} & \multirow[t]{2}{*}{$0.02^{*}$} \\
\hline & Female & 33.73 & 5.65 & & \\
\hline \multirow[t]{2}{*}{ Parents } & Male & 18.86 & 3.46 & \multirow[t]{2}{*}{-0.39} & \multirow[t]{2}{*}{0.70} \\
\hline & Female & 19.07 & 3.35 & & \\
\hline \multirow[t]{2}{*}{ Sibling } & Male & 19.17 & 4.00 & \multirow[t]{2}{*}{-0.19} & \multirow[t]{2}{*}{0.85} \\
\hline & Female & 19.29 & 3.70 & & \\
\hline \multirow[t]{2}{*}{ Friends } & Male & 18.23 & 3.65 & \multirow[t]{2}{*}{3.89} & \multirow[t]{2}{*}{$0.00 * *$} \\
\hline & Female & 16.26 & 2.84 & & \\
\hline \multirow[t]{2}{*}{ Relatives } & Male & 18.72 & 3.97 & \multirow[t]{2}{*}{1.83} & \multirow[t]{2}{*}{0.07} \\
\hline & Female & 17.58 & 3.83 & & \\
\hline \multirow{2}{*}{ Peers } & Male & 18.36 & 3.39 & \multirow{2}{*}{1.41} & \multirow{2}{*}{0.16} \\
\hline & Female & 17.63 & 3.12 & & \\
\hline \multirow[t]{2}{*}{ Teachers } & Male & 17.23 & 3.41 & \multirow[t]{2}{*}{-0.03} & \multirow[t]{2}{*}{0.98} \\
\hline & Female & 17.25 & 2.70 & & \\
\hline \multirow[t]{2}{*}{ Strangers } & Male & 16.88 & 2.62 & \multirow[t]{2}{*}{1.87} & \multirow[t]{2}{*}{0.06} \\
\hline & Female & 16.13 & 2.41 & & \\
\hline
\end{tabular}

*Significant at .05 level, **Significant at .01 level

The independent sample $t$ test has been applied on the data and the results from table 1 show that the $t$ ratio for overall social relationships is $1.73(\mathrm{p}=>.05)$ which is less than the critical value of .05 probability. Similarly, the $t$ ratios for parents, siblings relatives, peers and teachers also range between .98 to .06 all falling below the critical value of .05 probability level. This all indicates that there is no gender difference on overall social relationships and its above mentioned six dimensions. The findings go along with the study of Kumar et al. (2016) who suggested no significant gender differences on different dimensions of social relationships.

However, on friend dimension, the $t$ value of $3.89(\mathrm{p}<.01)$ is significant at .01 level of probability indicating male school children have significant higher level of relationship in comparison to their female counterparts. These results differ with the findings of Kumar et al. (2016). The reason might be that the Kumar et al. study has been conducted on University students and the current study includes school children. So in school, children might be more attached to their friends but the attachment level may change as they move to higher levels of life.

(c) The International Journal of Indian Psychology, ISSN 2348-5396 (e) | ISSN: 2349-3429 (p) | 131 


\section{Gender Differences in Social Relationships and Social Support of School Children}

Similarly, the $\mathrm{t}$ value $(\mathrm{t}=2.34, \mathrm{p}<.05)$ of social support also indicates a significant difference and suggest males are significantly higher on perceiving social support than girls. This finding go along with the results of Belle (1987), Walen and Lachman (2000) and Matud et al. (2003) who concluded that there is clear evidence of gender differences in perceived social support. Matud et al. (2003) also explained that this difference can be due to the different socialization and social roles performed by men and women.

\section{CONCLUSION}

In conclusion we can say that social relationships and social support are the key factors affecting one's physical and psychological health and overall males perceive higher social support and social networking in comparison to their female counterparts. The same is true in the case of school children. This suggests that female perceive low social support not only at higher stage of life, but this difference is rooted in their childhood and adolescent period also.

\section{Acknowledgments}

The author appreciates all those who participated in the study and helped to facilitate the research process.

\section{Conflict of Interests}

The author declared no conflict of interests.

\section{REFERENCES}

Adelman, M. B., Parks, M. R., \& Albrecht, T. L. (1987).Beyond close relationships: Support in weak ties. In T. L. Albrecht, M. B. Adelman, \& Associates (Eds.), Communicating social support. Newbury Park, CA: Sage.

Belle, D. (1987). Gender differences in the social moderators of stress. In R. C. Barnett, L. Biener, \& G. K. Baruch (Eds.), Gender and stress (pp. 257-277). New York: Free Press.

Bowlby, J. (1969). Attachment and loss: Attachment, New York: Basic

Cohen, S., Mermelstein, R., Kamarck, T., \& Hoberman, H. (1985). Measuring the functional components of social support. In I. G. Sarason \& B. R. Sarason (Eds.), Social support: Theory, research and application (pp. 73-94). The Hague, The Netherlands: Martinus Nijhoff.

Kumar, P., Nabi, F., Mujoo, S., Mir, A. I., Yangchen, R., Basra, R. Abdullahi, I. A., \& Yakasai, Y. T. (2016). Social Relationships in Students’ Life: Incentives or Liabilities in Mihir Kumar Mallick (Ed.), Teacher Education in 21st Century. New Delhi: New Delhi Publishers

Matud, M. P., Ibañez, I., Marrero, R. J., \& Carballeira, M. (2003). Diferencias en autoestima en función del género [Gender differences on self-esteem]. Análisis y Modificación de Conducta, 29, 51-78. 


\section{Gender Differences in Social Relationships and Social Support of School Children}

Schwarzer, R., \& Leppin, A. (1991). Social support and health: A theoretical and empirical overview. Journal of Social and Personal Relationships, 8, 99-127.

Walen H. R., \& Lachman M. E. (2000). Social Support and Strain from Partner, Family, and Friends: Costs and Benefits for Men and Women in Adulthood. Journal of Social and Personal Relationships, 17, 30.

How to cite this article: Parkash O (2016), Gender Differences in Social Relationships and Social Support of School Children, International Journal of Indian Psychology, Volume 4, Issue 1, No. 81, ISSN:2348-5396 (e), ISSN:2349-3429 (p), DIP:18.01.133/20160401, ISBN:978-1365-59365-9 